\title{
LOW-INCOME FAMILIES' PERCEPTIONS ON THE USE OF DRUGS BY ONE OF THEIR MEMBERS
}

\author{
Mayra Martins \\ Manoel Antonio dos Santos ${ }^{2}$ \\ Sandra Cristina Pillon ${ }^{3}$
}

Martins M, Santos MA, Pillon SC. Low-income families' perceptions on the use of drugs by one of their members. Rev Latino-am Enfermagem 2008 março-abril; 16(2):293-8.

Families who are socially excluded are vulnerable to problems related to the use of psychoactive substances. This study aimed to identify the perception regarding drugs use among families that lived in extreme poverty and participated in a social-educational group in the suburbs of a city in the interior of São Paulo State. A survey-like quantitative study was conducted involving 70 members of families who participated in the social-educational groups of the Program for Integral Assistance to the Family. Results indicated that 67 (95.7\%) of the subjects were married, at an average age of 37, most of them had not completed grade school, and were unemployed. Fifty five (78.6\%) had a family member who used alcohol, fifty two (74,3\%) smoked, and twenty three (32.9\%) used some kind of illicit drug. The results also showed that living with a relative who was a drug user was perceived as problem that elicited feelings resentment, but also conformism on the part of other family members.

DESCRIPTORS: Street drugs; family; poverty; development; risk factors

\section{PERCEPCIONES DE FAMILIAS CON BAJOS INGRESOS SOBRE EL CONSUMO DE DROGAS POR UM MIEMBRO DE SU FAMILIA}

En la actualidad, la familia ha sido valorada como un contexto de desarrollo fundamental para la adopción de comportamientos que pueden generar bienestar y promoción de la salud. Familias que son excluidas socialmente son vulnerables a presentar problemas relacionados al consumo de sustancias psicoactivas. El objetivo de ese estudio fue identificar la percepción que los familiares tienen sobre el consumo de drogas. Familias que viven en situación de pobreza extrema. Participantes de un grupo socio-educativo de los alrededores de una ciudad del interior del Estado de São Paulo. El tipo de estudio realizado fue tipo survey, con enfoque cuantitativo. Participaron 70 familiares de los grupos socio-educativos del Programa de Atención Integral a la Familia. Para la interpretación de los datos se utilizó la teoría del desarrollo basado en el curso de vida. Los resultados muestran que 67 (95.7\%) son casados, con edad promedio de 37 años y la mayoría tiene estudios primarios incompletos y se encuentran desempleados. El 78.6\% (55) tienen algún familiar que consume alcohol, 52 (74,3\%) cigarro y 23 (32.9\%) algún tipo de droga ilícita. El convivir con un familiar dependiente de drogas es percibido como un problema que genera sentimientos de indignación, al mismo tiempo , conformismo entre los familiares.

DESCRIPTORES: drogas ilícitas; familia; pobreza; desarrollo; factores de riesgo

\section{PERCEPÇÕES DE FAMÍLIAS DE BAIXA RENDA SOBRE O USO DE DROGAS POR UM DE SEUS MEMBROS}

Famílias que vivem em situação de exclusão social são vulneráveis a problemas relacionados ao uso de substâncias psicoativas. O objetivo deste estudo é identificar a percepção do uso de drogas entre familiares que vivem em situação de pobreza extrema, participantes de um grupo socioeducativo da periferia de uma cidade do interior do Estado de São Paulo. Foi realizado estudo do tipo survey, segundo enfoque quantitativo, com 70 familiares participantes dos grupos socioeducativos do Programa de Atenção Integral à Família. Os resultados indicam que $67(95,7 \%)$ são casados, com idade média de 37 anos, e a maioria possui ensino fundamental incompleto, estão desempregados e 55(78,6\%) possuem algum familiar que faz uso do álcool, 52(74,3\%) do cigarro e 23(32,9\%) algum tipo de droga ilícita. A convivência com um familiar usuário de drogas é percebida como problema que desperta sentimento de revolta, mas também conformismo, nos demais familiares.

DESCRITORES: drogas ilícitas; família; pobreza; desenvolvimento; fatores de risco

${ }^{1}$ Psychologist, M.Sc. in Violence and Chemical Dependency, e-mail: maymartins@uol.com.br; ${ }^{2}$ PhD, Faculty, University of Sao Paulo at Ribeirao Preto, Faculty of Philosophy, Letters and Human Sciences, Brazil, e-mail: masantos@ffclrp.usp.br; ${ }^{3}$ PhD, Faculty, University of São Paulo at Ribeirão Preto, School of Nursing, WHO Collaborating Center for Nursing Research Development, Brazil, e-mail: pillon@eerp.usp.br 


\section{INTRODUCTION}

Nowadays several studies show some aspects of the environment which must be considered in order to understand adaptation processes people experience during their lives; those processes influence people's behavior, which leads to well-being and health ${ }^{(1)}$. It is difficult to distinguish what is normal, what is pathological in that process, if development is solely considered from the perspective of life course, because it is a complex interaction which influences a person's future adaptation $^{(2)}$. One of the interaction aspects is related to family organization/operation.

Studies about human development have been focusing on the family's role in healthy evolution processes. Ecologically speaking, development is a dynamic set of interactions between human beings and the environment ${ }^{(3)}$ which includes the family. Those studies show that the family acts as development environment and as such they can minimize the consequences of risky situations. Protection procedures are related to life facts, resources, provisions or requests which can protect people from stressful events; risky factors can increase people's weakness for emotional and behavioral problems ${ }^{(4)}$.

Poverty is considered one of the main risky factors for human development. Studies show that socially excluded families have more problems related to use and abuse of psychoactive substances ${ }^{(5)}$. Alcoholism is one of the world's most serious risky factors for disease and death, especially in poor countries. According to the World Health Organization it is the third risky factor for health problems in developed countries and it is the first one in developing nations ${ }^{(6)}$.

The National Institute of Drug Abuse offers to help communities to understand the different risky factors and protection mechanisms related to drug use, violence and its consequences in order to prevent future individual biopsychosocial damage ${ }^{(7)}$. That institute believes that preventive actions have greatly contributed to that during the last years because they have been tested according to reality, that is, they have been adapted to the social-economic situation of target populations, and because they are easy to apply in the community.

The literature shows that early preventive strategies can help to reduce problems with drug abuse and violence. National studies show that it is possible to face those problems using proper public policies $^{(8)}$.

Several theories and models have been developed in order to explain and address preventive strategies which are going to be used. The Public Health model has been largely used for prevention of diseases in general and for use of alcohol and other drugs. This model consists of an epidemiological evaluation of a target problem and the identification of risky factors related to it, using the most common intervention procedures to decrease them. Therefore, it increases protective mechanisms which decrease the consequences of risky factors and monitor the impact of that intervention on the numbers of target diseases ${ }^{(9)}$. That model is the foundation for the strategies of the Brazilian health policies ${ }^{(10)}$.

According to that, the government suggests that the programs must concert actions in health, education, justice and society. They must include several preventive categories to help individuals and groups, educational workshops offered by different professionals, home visits and help, family assistance, activities for the whole community focusing the reintegration of the psychoactive substance user or dependent into society, community, and his/her family ${ }^{(11)}$.

However, doing so is not so easy because there is not enough literature in that area, especially about families who are vulnerable and in risky situations. There are only few studies about community socio-educational work focusing the biopsychosocial aspects of family with users of psychoactive substances, including aspects related to risk behavior and actions to improve health and prevent drug use.

The harbingers of individual preventive behavior in the environment include risky factors which show higher probability of problems and protection factors which moderate the risk, pointing to the lowest probability of use or dependence of psychoactive substances. Such evidence shows the need of having the family as an investigation unit, trying to define perceptions and conception about legal and illegal drugs.

The goal of this study is to identify the perception of use of alcohol and other drugs among family members who belong to a socio-educational 
group in a community in a suburb in Ribeirão Preto, a medium-sized city in São Paulo State, Brazil.

\section{METHOD}

Design of study

A quantitative cross-sectional study was developed.

Setting and context

The survey contains some comments of Psychology, Social Work and Nursing professionals that came up during socio-educational group meetings at the Program for Integral Family Care (PAIF). The PAIF is a continuing service of basic social protection, established by Decree Number 5085, May $19^{\text {th }}$, $2004^{(12)}$, which is developed at Reference Centers for Social Assistance (CRAS). Socio-educational groups target low income families who are registered and receive social financial benefits from the federal government.

The study was conducted in the northwest of Ribeirão Preto, in suburbs where crime rates and drug use are high. There the families are socially vulnerable, with no income or easy access to consumer products and public services because of their extreme poverty. The members of those families have fragile affective bonds and they are discriminated because of gender, ethnic group, disability, age, among others factors.

In Ribeirão Preto, a multiprofessional team from PAIF helps low income families in biopsychosocial risky situation. One of the assistance strategies used is the family group from where the participants of this study were selected. This survey was designed according to Resolution CNS196/96 and it was approved by the Ribeirão Preto Nursing School Ethics in Research Committee (process EERP-USP 0611/2005).

Theoretical-conceptual Reference

The reference is Rutter's theory of development based on life course which regards human development from a preventive perspective. Studies of that theoretical-conceptual conception identify risky factors and protection mechanisms, trying to evaluate their consequences in families that have an adverse daily life ${ }^{(2,3,13)}$.
Sample

Seventy $(40 \%)$ people registered in the social program in the northwest of the city participated in the study, and they were encouraged to participate in socio-educational groups too. Thus, there were 175 people participating on the study if the whole environment were considered, but more than $50 \%$ of them were not participating in the group, even though their presence was a requirement to keep on receiving the benefits. The participants were supposed to take part in at least one of the PAIF fortnightly meetings over a period of three months. It is important to say that only families that met the inclusion criteria to be included in federal government's social programs were assisted and for that they had to prove their extreme poverty.

Data collection

A structured questionnaire with sociodemographic information, the identification of a drug user in the family as well as the respondent's perception of the user's behavior was used to collect data. The researcher applied it individually and in a face-to-face environment. The study lasted three months and data collection took place at the end of the fortnightly meetings at PAIF when, on average, 15 people were present. There were 12 meetings in three months and some techniques were applied in order to raise awareness and help the interaction among the participants followed by group discussions about drug use and its consequences, interpersonal relationship with drug users and feelings and emotions related to the problem.

Data analysis

The collected data were organized in a worksheet. The Statistical Package Social Science-SPSS, version 11 data bank was used for statistical analysis. Descriptive statistical analysis (average, standard deviation) and Qui-square test were used to determine significant differences with a $95 \%$ of trust interval.

\section{RESULTS}

Table 1 shows that most of the PAIF participants were women: $67(95.7 \%)$ and married: 
$38(54.3 \%)$. The average age was 37 years old $(\mathrm{m}=$ 37.06; $\mathrm{dp}= \pm 12.24)$.

Forty-five $(64.3 \%)$ respondents had elementary level of education; most of them had not completed it. Forty-five $(64.3 \%)$ respondents were unemployed and 36 (51.4\%) received social benefits. Out of $34(48.6 \%)$ economically active respondents, $18(25.7 \%)$ were within the formal job market, working with manual activities which required little or no professional qualification, such as: seamstress, manicurist, maid, street cardboard picker, salesperson. The others were in underemployed it the informal job market.

Table 1 - Distribution of members of the northwest PAIF participant families, in relation to sociodemographics informations. Ribeirão Preto, São Paulo, 2006

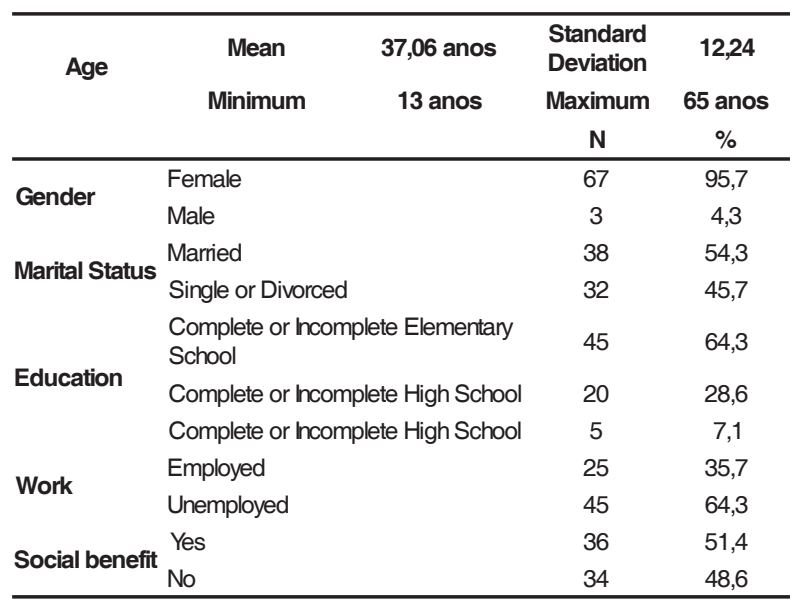

Family income of interviewed people was between $R \$ 60.00$ and $R \$ 2,048.00$ ( $\mathrm{md}=\mathrm{R} \$$ $547.00 ; \mathrm{Sd}= \pm \mathrm{R} \$ 433.00)$; mode is $\mathrm{R} \$ 300.00$ (value based on wages in 2005: R\$ 300.00); only 10 participants received more than 3 minimum wages. On average there were three children in each household ( $\mathrm{Sd}= \pm 1.96$ ), varying from 0 to 8 children and five people per household, varying from 2 to 11 inhabitants in each one. Those family residences were located in needy suburbs where there were few public services or assistance, which stimulated drug traffic and high rates of violence, robberies and homicides.

Twenty-three $(32.8 \%)$ participants answered that they themselves were responsible for financially supporting their family; $33(47.1 \%)$ husband or wife, and $14(20.1 \%)$ father and/or mother and/or brother/ sister. Thus, $36 \%(N=25)$ of the female participants take on the responsibility for their homes.
Table 2 - Distribution of PAIF participant families in northwest in relation to use of alcohol and other drugs among their members. Ribeirão Preto, São Paulo, 2006

\begin{tabular}{llcc}
\hline & & $\mathrm{N}$ & $\%$ \\
\hline is there anyone in the family who & Yes & 55 & 78.6 \\
drinks alcoholic drinks: & No & 15 & 21.4 \\
& Daily & 19 & 27.1 \\
Frequency & On the weekends & 24 & 34.3 \\
& More than 2 times a week & 12 & 17.1 \\
Is there anyone in the family who & Yes & 52 & 74.3 \\
smokes cigarette? & No & 18 & 25.7 \\
ss there anyone in the family who & Yes & 23 & 32.9 \\
uses other drugs? & No & 47 & 67.1 \\
& Marijuana & 5 & 7.1 \\
Kinds of drugs & Cocaine & 4 & 5.7 \\
& Crack & 14 & 20.1 \\
\hline
\end{tabular}

Table 2 shows that 55 (78.6\%) participants had someone in the family who drank alcoholic drinks, among them 24 (43.6\%) drank on weekends, 19 $(34.5 \%)$ drank daily and $12(21.8 \%)$ drank more than twice a week; 52 (74.3\%) participants had someone in the family who smoked; 23 (32.9\%) among them had someone in the family who used illegal drugs; most of them used more than one kind of drugs and $14(20.1 \%)$ of them used marijuana, cocaine and crack.

Table 3 compares family members' drinking and smoking habits. It shows that 48 (92.30\%) people used both of them at the same time.

Table 3 - Distribution of PAIF family members in northwest in relation to the presence of someone who drinks and smokes, Ribeirão Preto, São Paulo, 2006

\begin{tabular}{|c|c|c|c|c|c|c|c|}
\hline & & \multicolumn{4}{|c|}{ Smoke } & \multirow{2}{*}{\multicolumn{2}{|c|}{ Total }} \\
\hline & & & & & & & \\
\hline \multirow{2}{*}{ Drinks } & Yes & 48 & $92,3^{*}$ & 7 & 38,9 & 55 & 78,6 \\
\hline & No & 4 & 7,7 & 11 & 61,1 & 15 & 21,4 \\
\hline \multicolumn{2}{|c|}{ Total } & 52 & 100 & 18 & 100 & 70 & 100 \\
\hline
\end{tabular}

$* X^{2}=22.66 ; \mathrm{p} \leq 0.000$

Twenty-one (50\%) participants showed indignation and anger when they knew a family member was involved with drugs and 17 (40.5\%) showed conformism. In relation to the use of alcohol the feelings were similar although there were more alcohol users than drug users. Forty-seven participants $(67 \%)$ got along well with the user; $22(46.8 \%)$ had a regular relationship with him/her; $6(12.7 \%)$ had a bad relationship with him/her; and 4 (8.5\%) had a very bad relationship with him/her. 
Table 4 - Distribution of PAIF participant families in the northwest in relation to feelings and kind of relationship between family members and the users. Ribeirão Preto, São Paulo, 2006

\begin{tabular}{clcc}
\hline & & $\mathbf{N}$ & $\%$ \\
\hline Family reaction facing abuse of alcohol & Anger & 21 & 50 \\
and other drugs $(\mathrm{N}=42)$ & Conformism & 17 & 40,5 \\
& Other feelings & 4 & 9,5 \\
Kind of relationship between the drug & Good & 22 & 46,8 \\
user and family members ( $=47)$ & Regular & 15 & 31,9 \\
& Bad & 6 & 12,7 \\
& Very bad & 4 & 8,5 \\
\hline
\end{tabular}

Eighteen participants (39.0\%) stated that they did not support the user at all; 10 participants (22.0\%) said they offered a lot of support in order to help the user to deal with problems related to the use of alcohol and/or other drugs.

Twenty-nine participants $(41.4 \%)$ said that they had just a little information about the problems that alcohol use caused; 23 participants (32.9\%) had a lot of information and 18 (25.7\%) among them did not have any information at all.

Data also show that out of $42(60 \%)$, only 15 $(35.7 \%)$ families had already tried to get some treatment for the drug user, such as institutionalization at a recovery center (6) and mutual help groups (5); religion was also mentioned (4). Among those who had searched for help, only four followed the treatment. Fourteen families (33.3\%) said that they had some difficulty searching for treatment because of the distance from their houses.

\section{DISCUSSION}

PAIF participants were mainly women with low level of education, married and unemployed who received some kind of social benefit. That is why women were responsible for enforcing socioeducational measures for convict adolescent offenders, which was a requirement in order to continue receiving benefits from the government. Those women are also responsible for financially supporting their families and heading them.

Young women, during their psycho-affective development, take on, as a mother's role, actions like providing care and comfort. Thus, women develop empathy and interest for the others ${ }^{(1)}$.

The results of this study show rates relatively high for alcohol use (78.6\%), tobacco (74.3\%) and other drugs $(32.9 \%)$ in extremely poor families' reality and a high number of users of different kinds of drugs at the same time. Interviewed families reported that among them there were abusive and/ or dependent alcohol users. Three quarters of the families used tobacco and one third used other drugs. That fact is worrisome because it can cause or worsen psychosocial problems due to frequent use of drugs and the cost of drinking, smoking cigarettes and using other psychoactive substances.

These were poor families who depended on the financial support from the government so there was a concern about using part of that money to buy those substances. In other words, if they received a minimal benefit, how much did they take from that monthly income to buy alcohol, tobacco and drugs and how would that influence the family's survival? So, families who survive within poverty limits because of the social inequality caused by a poor distribution of income are even more vulnerable because of drugs. That said, it is possible to question if the level of risky situations that these participants experience are really soothed by the social benefits that they receive thanks to the federal government income distribution policies.

It is possible to deduce that the family system suffers from the consequences of drug dependence, the presence of a user among them and financial problems, which can lead to emotional unbalance. As a consequence, no family reorganization is possible and the resources for food and education are drained.

It is amazing that many participants showed some conformism, calm and resignation (completely different from a genuine acceptance) about having a family member who used drugs, especially alcohol. That can happen because alcohol is socially tolerated. Thinking about costs, it was expected that a family member, who is not a drug user, should be more assertive and warier because many times he/she has provide sustenance as well as finance the dependence of a substances user.

Most of the participants said that they had little or no information at all about drugs and that suggests that educational programs addressing this topic are necessary. Some studies focusing the psychosocial aspects of families that present problems with psychoactive substances use have made important contributions to find a solution to that issue.

One study pointed that substance use levels were higher when there was a user within the family. On the other hand, the origin of the problem is not only a biological matter (genetic factors) once it 
involves the structure of the relationships among the members of the family and between the family and a macro social system. In addition, genetic factors influence an individual's cognitive, behavioral and affective functioning which shows that if there is disharmony within the family, that disharmony can contribute to drug use.

As a consequence, the family system is a factor that must be considered both in the risk and protection contexts in order to understand the use of drugs among family members.

\section{CONCLUSIONS}

The socio-economic, cultural and educational profiles of the participants made it possible to draw the picture of the poverty experienced by families who are socially excluded, face chronic risks and are always vulnerable to drugs and often have problems with justice (offenses, law-breaking, crime) and other kinds of violence.

\section{REFERENCES}

1. Cecconello AM, Koller SH. Competência social e empatia: um estudo sobre resiliência com crianças em situação de pobreza. Estudos de Psicologia 2000; 5(1):71-93.

2. Aspesi CC, Dessen MA, Chagas JF. A ciência do desenvolvimento humano: uma perspectiva interdisciplinar. In: Dessen MA, Costa Junior AL, organizadores. A ciência do desenvolvimento humano: tendências atuais e perspectivas futuras. Porto Alegre, RS: Artmed; 2005.

3. Bronfenbrenner U. A ecologia do desenvolvimento humano: experimentos naturais e planejados. Porto Alegre: Artes Médicas; 1996.

4. Rutter M. Psychosocial resilience and protective mechanisms. American Journal of Orthopsychiatry 1987; (67):316-31.

5. OMS. Relatório Sobre a Saúde no Mundo. Saúde Mental: Nova Concepção, Nova Esperança. Genebra: Organização Mundial de Saúde; 2001.

6. World Health Organization. Neuroscience of psychoactive substance use and dependence [Summary] Genebra; 2004. 7. National Institute of Drug Abuse (NIDA), National Institutes of Health (NIH) publication N 99, 4212, 1997. cited 2007 April 28. Available from URL: http:// www.nida.nih.gov/ Prevention/Prevopen.html

8. Laranjeira R. Bases para uma política de tratamento dos problemas relacionados ao álcool e outras drogas no Estado de São Paulo. Jornal Brasileiro de Psiquiatria 1996; 45(4):191-9.
These are large families in relation to the members' low income and difficulties finding a job, which limits material conditions of survival and possibilities of positively solving problems of adaptation to a routine of frequent adversities. What can be done to offer alternative and affirmative models of survival to that population so that they can be away from drugs and crime? Socio-educational intervention programs, developed in the community targeting the prevention of health problems and reduction of risky behaviors, point that risky factors and protection mechanisms should be the main target of preventive strategies and that a model that enhances the empowerment of vulnerable families are the best way to prevent.

Having educational groups as PAIF is extremely necessary to develop family members' coping skills to deal with problems in a more resilient way, keeping the balance and well-being that are necessary to minimize conflicts and to disarm disruptive potential, working as health alternative models for the other family members.

9. Pillon SC, Luis MAV. Modelos explicativos para o uso do álcool e outras drogas e a prática da enfermagem. Rev. Latinoam enfermagem 2004; 12(4):951-82.

10. Hawkins JD, Catalano RF, Arthur MW. Promoting sciencebased prevention in communities. Addictive Behaviors 2002; (27): 951-76

11. Brasil. Ministério da Saúde. A política do Ministério da Saúde para Atenção Integral a Usuários de Álcool e Outras Drogas. $1^{a}$ ed. Brasília (DF): MS; 2003.

12. Brasil. Decreto no 5.085, de 19 de maio de 2004. Define as ações continuadas de assistência social.

13. Trombeta LHAP, Guzzo RSL. Enfrentando o cotidiano adverso: estudos sobre resiliência em adolescentes. Campinas (SP): Alínea 2002.

14. Cardoret RJ, O'Gorman TW, Troughton E, Heywood E. Alcoholism and antisocial personality: interrelationships, genetic, and environmental factors. Archives of General Psychiatry 1985; (42):161-7. 